\title{
Ambient Temperature Affects the Temperature Threshold for TRPM8 Activation through Interaction of Phosphatidylinositol 4,5-Bisphosphate
}

\author{
Fumitaka Fujita, ${ }^{1,2}$ Kunitoshi Uchida, ${ }^{1,3,4}$ Masayuki Takaishi, ${ }^{1,2}$ Takaaki Sokabe, ${ }^{1,4}$ and Makoto Tominaga ${ }^{1,3,4}$ \\ ${ }^{1}$ Section of Cell Signaling, Okazaki Institute for Integrative Bioscience, National Institutes of Natural Sciences, Okazaki 444-8787, Japan, ${ }^{2}$ Central Research \\ Laboratories, Mandom Corporation, Osaka 540-8530, Japan, ${ }^{3}$ National Institute for Physiological Sciences, Okazaki 444-8585, Japan, and ${ }^{4}$ Department of \\ Physiological Sciences, The Graduate University for Advanced Studies, Okazaki 444-8585, Japan
}

Cold sensation is an important and fundamental sense for animals and it is known to be affected by ambient temperature. Transient Receptor Potential Melastatin 8 (TRPM8), a nonselective cation channel expressed in a subset of peripheral afferent fibers, acts as a cold sensor, having an activation threshold of $\sim 28^{\circ} \mathrm{C}$. Although the cold temperature threshold of TRPM8 is affected by menthol or $\mathrm{pH}$, ambient temperature has not been reported to affect it. Because the cold temperature threshold was thought to be unchanged by alterations in ambient temperature, the relativity of temperature sensing in different ambient temperatures could not be understood at the level of molecular function of thermosensitive TRP channels. Here, we show that ambient temperature changed the temperature threshold for activation of human and rat TRPM8 in a heterologous expression system and cold responses in mouse DRG neurons. Moreover, reducing the level of cellular phosphatidylinositol 4,5-bisphosphate $\left(\mathrm{PIP}_{2}\right)$ attenuated changes in the cold temperature threshold after alterations in ambient temperature. A single amino acid mutation at position 1008 in the $\mathrm{C}$ terminus of TRPM8 (arginine to glutamine) also attenuated changes in the cold temperature threshold induced by ambient temperature. These findings suggest that ambient temperature does affect the temperature threshold for TRPM8 activation through interaction of PIP 2 .

\section{Introduction}

Temperature sensation is affected by initial or ambient temperature, as described concisely in the classical psychophysiological observations of the "three bowls experiment." Water at a neutral temperature causes a warm sensation if one first exposes one's hands to cold water; the same neutral temperature causes a cold sensation if one first exposes one's hands to warm water (Tritsch, 1990). Therefore, our sensation of altered temperature appears to be relative and it changes with the initial or ambient temperature.

Transient receptor potential (TRP) channels contribute to sensory transduction, responding to a wide variety of stimuli, including temperature and nociceptive stimuli. In particular, the involvement of TRP channels in thermosensation has been studied extensively after the cloning of the capsaicin receptor TRPV1 (Caterina et al., 1997; Tominaga and Caterina, 2004). Among

\footnotetext{
Received Dec. 12, 2012; revised Feb. 7, 2013; accepted March 1, 2013.

Author contributions: F.F., K.U., and M. Tominaga designed research; F.F., K.U., and M. Takaishi performed research; F.F., K.U., M. Takaishi, T.S., and M. Tominaga analyzed data; F.F. and M. Tominaga wrote the paper.

This work was supported by the Ministry of Education, Culture, Sports, Science and Technology in Japan (to M.T.). Experiments using HEK293cells expressing TRPM8 or TRPA1 were performed in collaboration with Mandom. We thank Drs. Y. Kubo and M. Tateyama for help with the FRET experiment and N. Fukuta for technical assistance.

Correspondence should be addressed to either of the following: Dr. M. Tominaga, Section of Cell Signaling, Okazaki Institute for Integrative Bioscience, National Institutes of Natural Sciences, Okazaki, Aichi 444-8787, Japan, E-mail: tominaga@nips.ac.jp; or Dr. F. Fujita, Central Research Laboratories, Mandom Corporation, 0saka, Osaka 540-8530, Japan, E-mail: fujita-f@mandom.co.jp.

DOI:10.1523/JNEUROSCI.5672-12.2013

Copyright $@ 2013$ the authors $\quad 0270-6474 / 13 / 336154-06 \$ 15.00 / 0$
}

TRP channels, TRPM8 has been proposed for detection of cold temperatures in the innocuous and noxious ranges (McKemy et al., 2002; Knowlton et al., 2010). This channel is also activated by cooling agents such as menthol and icilin (McKemy et al., 2002; Peier et al., 2002; Chuang et al., 2004), voltage (Brauchi et al., 2004; Voets et al., 2004), and phosphatidylinositol 4,5bisphosphate ( $\mathrm{PIP}_{2}$; Liu and Qin, 2005; Rohács et al., 2005; Daniels et al., 2009; Zakharian et al., 2010; Yudin et al., 2011), which regulates the activity of a variety of ion channels (Hilgemann et al., 2001). Direct inhibition of TRPM8 by $\mathrm{G} \alpha_{\mathrm{q}}$ has also been described recently (Zhang et al., 2012). Modulation by $\mathrm{PIP}_{2}$ has been shown for several TRP channel members (Rohács and Nilius, 2007). TRPL (Estacion et al., 2001) and TRPV1 (Chuang et al., 2001) are inhibited through interaction with PIP $_{2}$, whereas TRPM5 (Liu and Liman, 2003), TRPM7 (Runnels et al., 2002) and TRPM8 (Liu and Qin, 2005; Rohács et al., 2005; Zakharian et al., 2010) are activated.

Temperature thresholds for TRPM8 activation are affected by a variety of factors. Menthol shifts the temperature threshold for TRPM8 activation to higher temperatures (McKemy et al., 2002; Mälkiä et al., 2007). Conversely, in the presence of the TRPM8 antagonists BCTC or SKF96365, the temperature thresholds for TRPM8 activation are shifted to lower temperatures (Mälkiä et al., 2007). The temperature thresholds for TRPM8 activation were shown to be elevated at a higher $\mathrm{pH}$ and decreased at a lower $\mathrm{pH}$ (Andersson et al., 2004). High concentrations of $\mathrm{PIP}_{2}$ activate TRPM8 channels even in the $32-37^{\circ} \mathrm{C}$ range, warmer than the 
Table 1. Synthetic oligonucleotide primers constructing specific mutations

\begin{tabular}{|c|c|c|}
\hline & Sense primer $\left(5^{\prime} \rightarrow 3^{\prime}\right)$ & Antisense primer $\left(5^{\prime} \rightarrow 3^{\prime}\right)$ \\
\hline K9950 & AGAACAATGACCAGGTCTGGCAGTTCCAGAGGTAC & CCAGACCTGGTCATTGTTCTCCTGGACGGTG \\
\hline R9980 & ACCAGGTCTGGAAGTTCCAGCaGTACTTCCTGGTG & CTGGAACTTCCAGACCTGGTCATTGTTCTC \\
\hline R1008Q & TGGTGCAGGAGTACTGCAGCCaаCTCAATATCC & GGCTGCAGTACTCCTGCACCAGGAAGTACCTCTG \\
\hline Y745H & TCTCCTGGAATGTGGTCTTCACATCGCCTTCCTCCTG & GAAGACCACATTCCAGGAGAAGACCACGAAG \\
\hline Y1005F & GGTACTTCCTGGTGCAGGAGTtCTGCAGCCGCCTCAATATCC & CTCCTGCACCAGGAAGTACCTCTGGAACTTCCAGAC \\
\hline L1009R & TGCAGGAGTACTGCAGCCGCCgCAATATCCCCTTC & GCGGCTGCAGTACTCCTGCACCAGGAAGTACCTC \\
\hline N799A & ATTATTTTACTGACCTGTGGgCTGTGATGGACACGCTG & CCACAGGTCAGTAAAATAATTCACCCCATTTACG \\
\hline D802A & CTGACCTGTGGAATGTGATGGCCACGCTGGGGCTTTTTTAC & CATCACATTCCACAGGTCAGTAAAATAATTCAC \\
\hline G805A & GGAATGTGATGGACACGCTGGccCTTTTTTACTTCATAG & CAGCGTGTCCATCACATTCCACAGGTCAG \\
\hline
\end{tabular}

Lowercase letters indicate substituted bases.

threshold under naive conditions (Rohács et al., 2005). Lipid raft disruption also shifts the temperature thresholds for TRPM8 activation (Morenilla-Palao et al., 2009). Although the molecular mechanisms underlying the three bowls experiment are not known, some of the factors described above could be related to the phenomenon. In contrast, it is generally believed that temperature thresholds for TRPM8 activation are not affected by changes in ambient or initial temperature.

In the present study, we demonstrate that temperature thresholds for mammalian TRPM8 activation are modified in vitro by changes in ambient temperature. Moreover, we determined that the interaction of $\mathrm{PIP}_{2}$ is important for modifying the temperature threshold for activation.

\section{Materials and Methods}

Cell culture. Human embryonic kidney-derived 293T (HEK293T) cells were maintained in DMEM (WAKO Pure Chemical Industries) supplemented with $10 \%$ FBS (Biowest), 100 units/ml penicillin (Life Technologies), $100 \mu \mathrm{g} / \mathrm{ml}$ streptomycin (Life Technologies), and two $\mathrm{mm}$ L-glutamine (GlutaMAX; Life Technologies) at $37^{\circ} \mathrm{C}$ in $5 \% \mathrm{CO}_{2}$. For $\mathrm{Ca}^{2+}$ imaging, $1 \mu \mathrm{g}$ of plasmid DNA containing human TRPM8 (Life Technologies), rat TRPM8 (provided by Dr. David Julius, University of California-San Francisco), mutant human TRPM8 with or without CiVSP (provided by Dr. Yasushi Okamura, Osaka University, Osaka, Japan) or rat EP1 (provided by Dr. Shu Narumiya, Kyoto University, Kyoto, Japan) in pcDNA3 in OPTI-MEM medium (Life Technologies) were transfected into HEK293T cells using Lipofectamine Plus Reagent (Life Technologies). After incubating for 3-4 h, the cells were reseeded on coverslips and further incubated at $37^{\circ} \mathrm{C}$ in $5 \% \mathrm{CO}_{2}$. DRG cells were rapidly isolated from male $\mathrm{C} 57 \mathrm{Bl} / 6 \mathrm{NCr}$ mice $(4-6$ weeks old; SLC; Hamamatsu) and used for the experiments in the following day. All procedures involving the care and use of animals were approved by the Institutional Animal Care and Use Committee of the National Institutes of Natural Sciences and were performed in accordance with the National Institutes of Health's Guide for the Care and Use of Laboratory Animals (NIH publication \#85-23, revised 1985).

TRPM8 mutants. Vectors containing the full-length mutants were constructed by single amino acid substitutions using a GeneTailor SiteDirected Mutagenesis System (Invitrogen). Synthetic oligonucleotide primers constructing specific mutations are shown in Table 1 . The entire sequence, including the desired substitution in the mutants, was confirmed by DNA sequencing.

$\mathrm{Ca}^{2+}$ imaging. HEK293T cells on coverslips were mounted in an open chamber and rinsed with standard bath solution containing the following (in $\mathrm{mm}): 140 \mathrm{NaCl}, 5 \mathrm{KCl}, 2 \mathrm{MgCl}_{2}, 2 \mathrm{CaCl}_{2}, 10$ HEPES, and 10 glucose, $\mathrm{pH}$ 7.4. Cytosolic free intracellular $\mathrm{Ca}^{2+}$ concentration $\left(\left[\mathrm{Ca}^{2+}\right]_{\mathrm{i}}\right)$ in HEK293 cells was measured by dual-wavelength fura-2 (Invitrogen) microfluorometry with excitation at $340 / 380 \mathrm{~nm}$ and emission at $510 \mathrm{~nm}$. The ratio image was calculated and acquired using the IP-Lab imaging processing system (Scanalytics). Temperature thresholds were defined as temperatures causing ratio increases in menthol-sensitive cells.

Electrophysiology. Whole-cell patch-clamp recordings were performed $1 \mathrm{~d}$ after transfection. The standard bath solution was the same as that used in the $\mathrm{Ca}^{2+}$-imaging experiments. To make a $\mathrm{Ca}^{2+}$-free bath solution, $\mathrm{CaCl}_{2}$ was omitted and $5 \mathrm{~mm}$ EGTA was added. The pipette solution contained $140 \mathrm{~mm} \mathrm{KCl}, 5 \mathrm{~mm}$ EGTA, and $10 \mathrm{~mm}$ HEPES, pH 7.4 (adjusted with $\mathrm{KOH}$ ). Data from whole-cell voltage-clamp recordings were sampled at $10 \mathrm{kHz}$ and filtered at $5 \mathrm{kHz}$ for analysis (Axon 200B amplifier with pCLAMP software; Molecular Devices). Membrane potential was clamped at $-60 \mathrm{mV}$. All experiments were performed at room temperature. Cold stimulation was induced by lowering the bath temperature with an ice-chilled solution at a constant bath temperature with an inline heater or heating stage. Temperature was monitored with a thermocouple (TA-29; Warner Instruments) placed within $100 \mu \mathrm{m}$ of the patchclamped cell. Current densities were plotted on a logarithmic scale against the reciprocal of the absolute temperature in an Arrhenius plot, with the temperature threshold defined as the temperature at the intersection of the two extrapolation lines before and after channel activation. To evaluate the temperature threshold in the presence of m-3M3FBS (Sigma-Aldrich), wortmannin (Sigma-Aldrich), $\mathrm{PIP}_{2}$ specific antibody (Abcam), or dioctanoyl $\mathrm{PIP}_{2}\left(\mathrm{diC}_{8} \mathrm{PIP}_{2}\right.$, Sigma-Aldrich), the entire experiment was performed in the presence of $\mathrm{m}$-3M3FBS $(30 \mu \mathrm{M})$, wortmannin $(10 \mu \mathrm{M}), \mathrm{PIP}_{2}$ specific antibody $(1 / 80)$, or $\operatorname{diC}_{8} \mathrm{PIP}_{2}(20 \mu \mathrm{M})$.

Data analysis. Data are expressed as means \pm SEM. Student's $t$ test was used to compare the data between two groups. $p<0.05$ was considered significant.

\section{Results}

We first examined whether temperature thresholds for TRPM8 activation could be changed depending on the temperature to which the cells were exposed. We used $\mathrm{Ca}^{2+}$ imaging of HEK293T cells expressing human TRPM8 (hTRPM8) or rat TRPM8 (rTRPM8). At $40^{\circ} \mathrm{C}$ ambient (initial) temperature, temperature thresholds were $\sim 35^{\circ} \mathrm{C}\left(35.0 \pm 0.7^{\circ} \mathrm{C}, n=8\right.$ for hTRPM 8 and $34.5 \pm 0.8^{\circ} \mathrm{C}, n=7$ for rTRPM 8$)$. In contrast, they were $\sim 28^{\circ} \mathrm{C}\left(28.3 \pm 0.5^{\circ} \mathrm{C}, n=7\right.$ for hTRPM 8 and $28.6 \pm 0.5^{\circ} \mathrm{C}$, $n=7$ for rTRPM8) when the ambient temperature was $30^{\circ} \mathrm{C}$ (Fig. $1 A, B)$. To confirm the effect of initial temperature on temperature threshold for TRPM8 activation in native sensory neurons, we performed $\mathrm{Ca}^{2+}$-imaging experiments with isolated mouse DRG neurons. In the subset of DRG neurons that showed an increase in $\left[\mathrm{Ca}^{2+}\right]_{\mathrm{i}}$ when exposed to ice-chilled bath solution, temperature thresholds for $\mathrm{a}\left[\mathrm{Ca}^{2+}\right]_{\mathrm{i}}$ increase were $32.7 \pm 0.5^{\circ} \mathrm{C}$ at an initial temperature of $40^{\circ} \mathrm{C}$ and $28.8 \pm 0.6^{\circ} \mathrm{C}$ at a $30^{\circ} \mathrm{C}$ initial temperature $(n=10)$. These results were similar to those observed in HEK293T cells expressing TRPM8 (Fig. 1B). More precise analyses of changes in temperature thresholds for TRPM8 activation were performed by making Arrhenius plots for TRPM8-mediated current responses at various exposed temperatures. The increase in the exposed temperature from $30^{\circ} \mathrm{C}$ to $40^{\circ} \mathrm{C}$ increased the temperature thresholds for TRPM8 activation from $28.3 \pm 0.4$ to $33.8 \pm 1.1^{\circ} \mathrm{C}(n=6)$ in HEK293 cells expressing hTRPM8 (Fig. 1C,D). The fact that lowering the exposed temperature from $40^{\circ} \mathrm{C}$ to $30^{\circ} \mathrm{C}$ produced similar changes in tem- 
perature thresholds from $32.8 \pm 0.9$ to $28.2 \pm 0.8^{\circ} \mathrm{C}(n=5$; Fig. $1 E, F)$ indicated that the difference in the change of direction of the exposed temperature was not related to the changes in temperature threshold. The exposed-temperaturedependent changes in temperature thresholds for TRPM8 activation were also observed with rTRPM8 and were further supported by multi-exposed temperature point analysis (Fig. 2A).

Because TRPM8 is reportedly regulated downstream of the cascade through phospholipase C (PLC) and $\mathrm{PIP}_{2}$ (Liu and Qin, 2005; Rohács et al., 2005; Daniels et al., 2009; Yudin et al., 2011), we hypothesized that they might be involved in the exposed-temperature-dependent changes in temperature thresholds for TRPM8 activation. Therefore, various chemicals affecting this cascade were tested to determine whether the changes in temperature thresholds for hTRPM8 activation were influenced by $\mathrm{PIP}_{2}$-related events. In treatments with a benzenesulfonamide compound, m-3M3FBS (30 $\mu \mathrm{M})$, which activates all isoforms of PLC (Horowitz et al., 2005; Daniels et al., 2009), the exposed-temperature-dependent changes in temperature thresholds for hTRPM8 activation became significantly lower $\left(26.7 \pm 0.2^{\circ} \mathrm{C}\right.$ at $30^{\circ} \mathrm{C}$ and $28.5 \pm$ $0.2^{\circ} \mathrm{C}$ at $40^{\circ} \mathrm{C}, n=17, p<0.01$; Fig. $\left.2 A, B\right)$. Moreover, $10 \mu \mathrm{M}$ wortmannin, an inhibitor of phosphatidylinositol 4-kinase (Nakanishi et al., 1995), and a $\mathrm{PIP}_{2}$ specific antibody, both of which are supposed to reduce the amount of functional $\mathrm{PIP}_{2}$ (Benedikt et al., 2007), also eliminated the changes in temperature threshold for hTRPM8 activation by exposed temperatures between $30^{\circ} \mathrm{C}$ and $40^{\circ} \mathrm{C}\left(24.3 \pm 1.3^{\circ} \mathrm{C}\right.$ at $30^{\circ} \mathrm{C}$ and $26.6 \pm 0.9^{\circ} \mathrm{C}$ at $40^{\circ} \mathrm{C}$ with wortmannin, $n=8 ; 25.5 \pm 0.6^{\circ} \mathrm{C}$ at $30^{\circ} \mathrm{C}$ and $28.9 \pm$ $1.3^{\circ} \mathrm{C}$ at $40^{\circ} \mathrm{C}$ with a $\mathrm{PIP}_{2}$ specific antibody, $n=8$; Fig. $2 B$ ). However, addition of $20 \mu \mathrm{M} \mathrm{diC}$ PIP $_{2}$, a synthetic PIP 2 (Rohács et al., 2005), showed significant differences in temperature thresholds for hTRPM8 activation between exposure temperatures of $40^{\circ} \mathrm{C}$ and $30^{\circ} \mathrm{C}\left(26.2 \pm 0.5^{\circ} \mathrm{C}\right.$ at $30^{\circ} \mathrm{C}$ and $33.1 \pm 0.9^{\circ} \mathrm{C}$ at $\left.40^{\circ} \mathrm{C}, n=7\right)$, although temperature thresholds at $30^{\circ} \mathrm{C}$ exposed temperature were slightly higher than control (Fig. $2 B$ ). To determine the involvement of $\mathrm{Ca}^{2+}$ influx in the exposed-temperaturedependent changes in temperature thresholds for hTRPM8 activation, we performed patch-clamp experiments in the absence of extracellular $\mathrm{Ca}^{2+}$ (Fig. 2B). The exposed-temperature-dependent changes in temperature thresholds for hTRPM8 activation were also observed in the absence of extracellular $\mathrm{Ca}^{2+}\left(25.3 \pm 0.4^{\circ} \mathrm{C}\right.$ at $30^{\circ} \mathrm{C}$ and $30.2 \pm 0.4^{\circ} \mathrm{C}$ at $40^{\circ} \mathrm{C}, n=10$ ). These results suggest that $\mathrm{PIP}_{2}$, but not $\mathrm{Ca}^{2+}$ influx, was involved in the changes in temperature thresholds for hTRPM8 activation.

Previous studies with TRPM8 mutants identified the important residues required for interaction with $\mathrm{PIP}_{2}$ (Rohács and Nilius, 2007), menthol (Bandell et al., 2006) or icilin (Chuang et al., 2004). Therefore, we sought to identify the amino acids involved in the exposed-temperature-dependent changes in
B
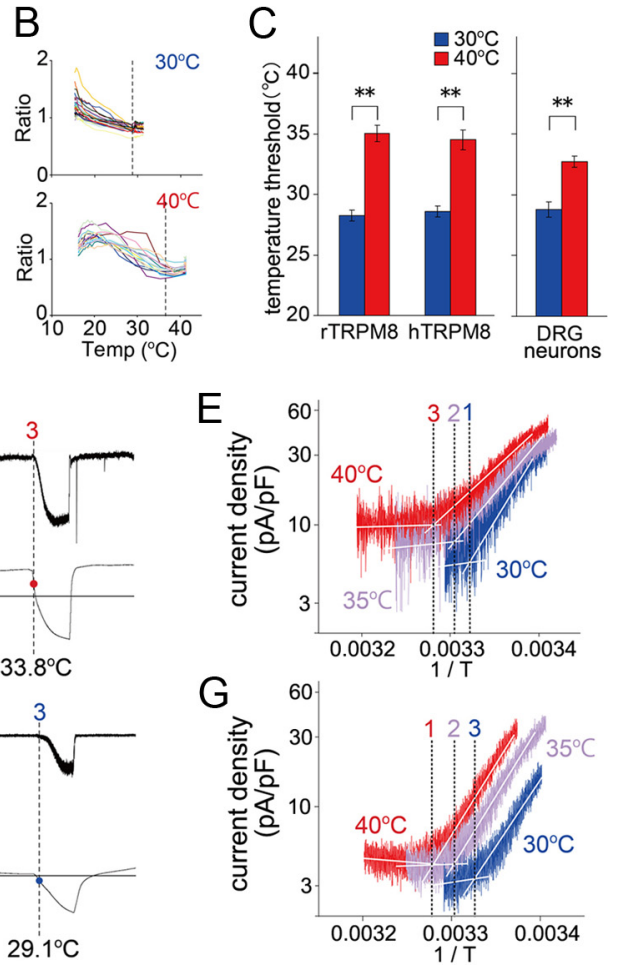

Figure 1. Temperature thresholds of TRPM8 activation are affected by the ambient temperatures in both HEK293 cells expressing TRPM8 and native sensory neurons. $\boldsymbol{A}, \boldsymbol{B}$, Cold stimulus increased the cytosolic $\mathrm{Ca}^{2+}$ concentration. Data are presented as the fura-2 ratio (340/380 mm) in HEK293T cells expressing human TRPM8 (hTRPM8) in the presence of extracellular Ca ${ }^{2+}$ after 3 min

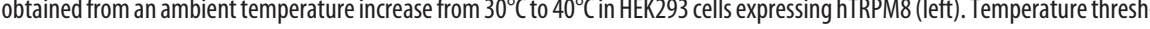
(left). Temperature thresholds for hTRPM 8 activation at $30^{\circ} \mathrm{C}, 35^{\circ} \mathrm{C}$, and $40^{\circ} \mathrm{C}$ in the temperature-decreasing protocol were $28.2 \pm$ $0.8,31.1 \pm 0.7$, and $32.8 \pm 0.9^{\circ} \mathrm{C}$, respectively $(n=5) .{ }^{* *} p<0.01$.

temperature thresholds for TRPM8 activation. We investigated whether temperature thresholds for TRPM8 activation at an exposed temperature of $40^{\circ} \mathrm{C}$ were affected in the reported TRPM8 mutants. We used $\mathrm{Ca}^{2+}$-imaging to characterize cells expressing hTRPM8 mutants. Like the wild-type, most of the mutants exhibited high temperature thresholds for activation at an initial temperature of $40^{\circ} \mathrm{C}$. However, the R1008Q mutant, in which the 1008th residue, arginine, in the $\mathrm{C}$-terminal region, an interacting site for $\mathrm{PIP}_{2}$ (Rohács et al., 2005), was changed to glutamine, exhibited a significantly lower threshold than wild-type hTRPM8 $\left(35.3 \pm 0.6^{\circ} \mathrm{C}\right.$ in wild-type and $31.8 \pm 0.9^{\circ} \mathrm{C}$ in the $\mathrm{R} 1008 \mathrm{Q}$ mutant, $n=5, p<0.05$; Fig. $2 C$ ).

We next investigated whether R1008Q preserved the exposedtemperature-dependent changes in temperature thresholds using a patch-clamp method. The exposed-temperature-dependent changes in temperature thresholds observed in the wild-type were lost in R1008Q $\left(26.0 \pm 0.8^{\circ} \mathrm{C}\right.$ at $30^{\circ} \mathrm{C}$ and $27.9 \pm 1.2^{\circ} \mathrm{C}$ at $\left.40^{\circ} \mathrm{C}, n=10\right)$. However, $\mathrm{K} 995 \mathrm{Q}$, which is also a mutant reported as being an interacting site for $\mathrm{PIP}_{2}$, exhibited changes in the temperature thresholds like that in the wild-type $\left(27.3 \pm 0.5^{\circ} \mathrm{C}\right.$ at $30^{\circ} \mathrm{C}$ and $33.2 \pm 0.9^{\circ} \mathrm{C}$ at $40^{\circ} \mathrm{C}, n=9$; Fig. $\left.2 D, E\right)$. These results suggested that $\mathrm{PIP}_{2}$ interaction with R1008 of hTRPM8 was necessary for the exposed-temperature-dependent changes in temperature thresholds. 
A

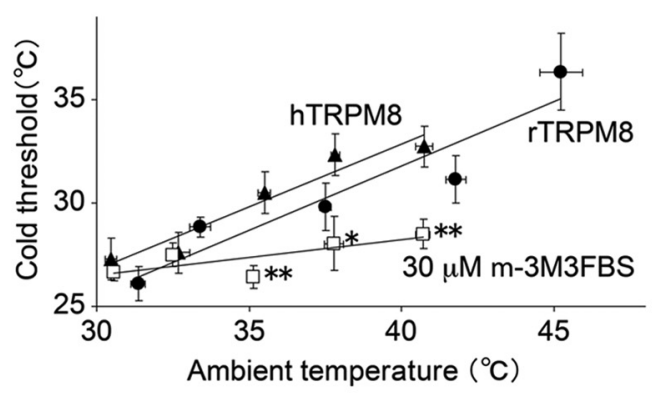

C

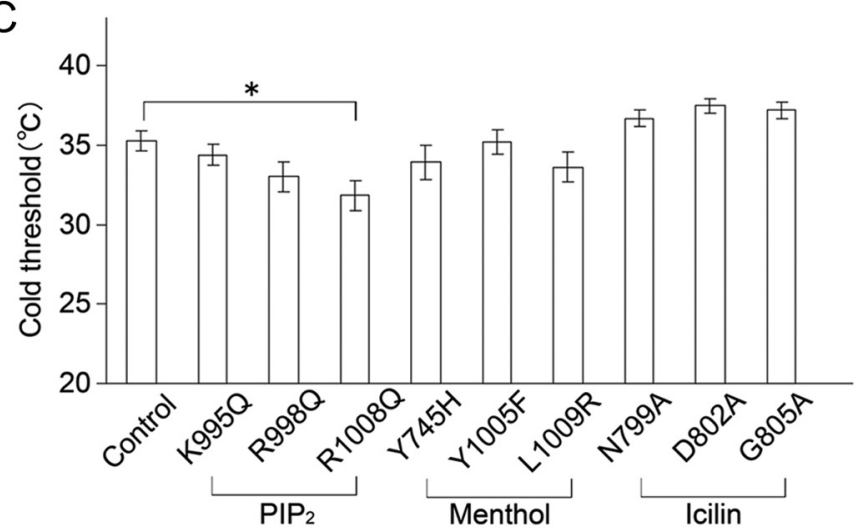

D

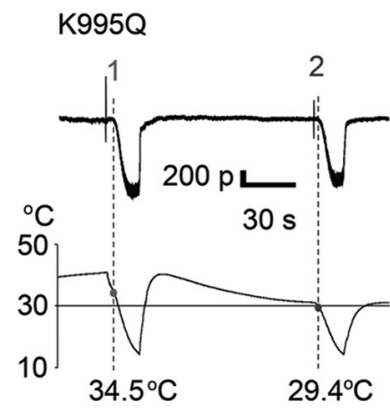

B

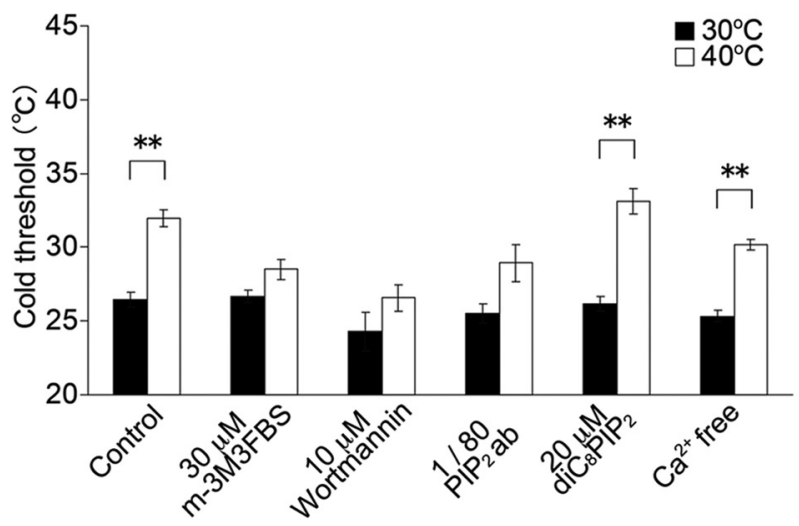

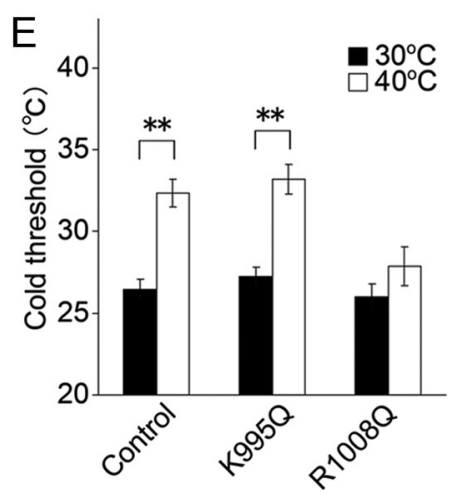

$\mathrm{F}$

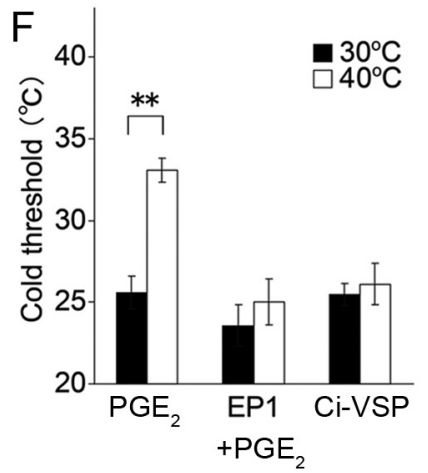

Figure 2. Changes in temperature thresholds of TRPM8 activation depending on the exposed temperature involved PIP 2 interaction with TRPM8. A, Temperature thresholds for both hTRPM8 (closed triangles, $n=16$ ) and rTRPM8 (closed circles, $n=7$ ) activation increased depending on the elevation of the preexposure temperature in HEK293T cells, which was not observed in the treatment with m-3M3FBS, a PLC activator (open squares, $n=17$ ) using a patch-clamp method. $B$, Changes in temperature thresholds for human TRPM8 activation between $40^{\circ} \mathrm{C}$ and $30^{\circ} \mathrm{C}$ exposed ambient temperatures without (Control, $n=16$ ) or with chemicals affecting cytosolic $\mathrm{PIP}_{2}$ actions ( $30 \mu \mathrm{m} \mathrm{m}-3 \mathrm{M} 3 \mathrm{FBS}, n=17 ; 10 \mu \mathrm{m}$ wortmannin, a specific PIP ${ }_{2}$ antibody, $n=8 ; 20 \mu \mathrm{m}$ diC ${ }_{8} \mathrm{PIP}_{2}$, $n=8)$ in pipette solutions, or a $\mathrm{Ca}^{2+}$-free condition $(n=10)$ using a patch-clamp method. $C$, Temperature thresholds for fura-2 ratio increase at $40^{\circ} \mathrm{C}$ of exposed temperature in the HEK293T cells expressing different TRPM8 mutants using a $\mathrm{Ca}^{2+}$-imaging method $(n=5-9)$. D, Representative traces of the currents activated by cold stimulus in HEK293T cells expressing mutant hTRPM8 $(\mathrm{K} 995 \mathrm{Q}, \mathrm{R} 1008 \mathrm{Q})$ at the exposed temperature change from $40^{\circ} \mathrm{C}$ to $30^{\circ} \mathrm{C}$. E, Changes in temperature thresholds for wild-type $(n=11)$ and mutant hTRPM8 $(n=9$ for K995Q, $n=10$ for R1008Q) in HEK293 cells between $40^{\circ} \mathrm{C}$ and $30^{\circ} \mathrm{C}$ exposed ambient temperatures. $\boldsymbol{F}$, Changes in temperature thresholds for hTRPM8 activation in HEK293 cells expressing TRPM8 upon treatment with PGE (left, $n=5$ ), cells expressing human TRPM8 and rat EP1 upon treatment with PGE (middle, $n=8$ ), and cells expressing human TRPM8 and rat Ci-VSP upon voltage step ( $+100 \mathrm{mV}$ for $30 \mathrm{~s}$ after $-60 \mathrm{mV}$ for $3 \mathrm{~min}$; right, $n=11) .{ }^{*} p<0.05 ;{ }^{* *} p<0.01$.

PIP $_{2}$ levels can be regulated by different pharmacological approaches from those described above. For example, the amount of $\mathrm{PIP}_{2}$ is reduced downstream of activation of Gq-proteincoupled receptors. We sought to further confirm the involvement of $\mathrm{PIP}_{2}$ in the exposed-temperature-dependent changes in temperature thresholds for TRPM8 activation. We treated HEK293T cells expressing mouse EP1 and hTRPM8 with prostaglandin $\mathrm{E}_{2}\left(\mathrm{PGE}_{2}, 1 \mu \mathrm{M}\right)$. These agents cause TRPV1 sensitization through a Gq-protein-dependent process (Moriyama et al.,
2005). Changes in temperature threshold for TRPM8 activation between $30^{\circ} \mathrm{C}$ and $40^{\circ} \mathrm{C}$ were lost after $\mathrm{PGE}_{2}$ treatment (23.6 \pm $1.3^{\circ} \mathrm{C}$ at $30^{\circ} \mathrm{C}$ and $25.0 \pm 1.4^{\circ} \mathrm{C}$ at $40^{\circ} \mathrm{C}$ upon $\mathrm{PGE}_{2}$ application in cells expressing EP1, $n=8$, Fig. $2 F)$. PGE $_{2}$ application alone caused no changes in cells without EP $1\left(25.6 \pm 1.0^{\circ} \mathrm{C}\right.$ at $30^{\circ} \mathrm{C}$ and $33.1 \pm 0.7^{\circ} \mathrm{C}$ at $40^{\circ} \mathrm{C}$ upon $\mathrm{PGE}_{2}$ application, $n=5, p<0.01$ ). However, direct inhibition of TRPM8 by $\mathrm{G} \alpha_{\mathrm{q}}$ (Zhang et al., 2012) could cause similar outcomes. Therefore, we used a different approach with Ciona intestinalis voltage-sensor-containing 
phosphatase (Ci-VSP), which acts as a phosphatase for the 5-phosphate of $\mathrm{PI}(4,5) \mathrm{P}_{2}$ upon membrane voltage changes (Iwasaki et al., 2008). We maintained HEK293T cells expressing Ci-VSP and hTRPM8 at $+100 \mathrm{mV}$ for $30 \mathrm{~s}$ after being given a voltage of $-60 \mathrm{mV}$ for $3 \mathrm{~min}$, which was reported previously to reduce $\mathrm{PIP}_{2}$ through dephosphorylation (Iwasaki et al., 2008). The exposed-temperature-dependent changes in temperature thresholds for TRPM8 activation were also lost $\left(25.5 \pm 0.7^{\circ} \mathrm{C}\right.$ at $30^{\circ} \mathrm{C}, n=11$ and $26.1 \pm 1.3^{\circ} \mathrm{C}$ at $40^{\circ} \mathrm{C}$ upon voltage step, $n=9$; Fig. $2 F)$. These results further support the concept that PIP $_{2}$ action on TRPM8 is important for causing changes in temperature thresholds for TRPM8 activation.

\section{Discussion}

Thermosensitive TRP channels are remarkable for their ability to sense a wide range of temperatures. However, only some of the known thermosensitive TRP channels are thought to sense the ambient temperature in either sensory neurons or skin keratinocytes (TRPV1, TRPM8, TRPA1, TRPV3 and TRPV4; TRPV2 involvement in thermal nociception has been questioned by Park et al., 2011). How do our bodies acquire such a marked ability to sense ambient temperature changes as small as $1^{\circ} \mathrm{C}$ ? It could be achieved by dynamic changes in temperature thresholds for activation. Indeed, capsaicin receptor TRPV1 exhibited a reduction in temperature threshold through serine phosphorylation by protein kinases $\mathrm{A}$ and $\mathrm{C}$ upon proinflammatory mediator production (Tominaga and Caterina, 2004). It was reported that the lipid environment could change the temperature threshold for TRPM8 activation (Rohács et al., 2005; Morenilla-Palao et al., 2009). In addition, minimal amounts of agonists for TRPV1 or TRPM8 reduce or increase, respectively, their temperature thresholds for activation. Furthermore, we reported recently that temperature thresholds for activation of the temperaturesensitive TRPM2 channel could be reduced through hydrogenperoxide-mediated oxidation of methionine in the $\mathrm{N}$ terminus (Kashio et al., 2012).

In the present study, we have provided conclusive evidence that temperature thresholds for activation of mammalian TRPM8 can be changed dynamically by a relatively brief exposure to different ambient temperatures through a mechanism involving PIP $\mathrm{P}_{2}$. We also identified a single arginine residue that could be involved in the exposed-temperature-dependent changes in temperature thresholds for TRPM8 activation. We propose that the $\mathrm{PIP}_{2}$-mediated mechanism observed in this study could contribute to the three bowls experiment.

Although we are confident that the interaction of $\mathrm{PIP}_{2}$ with TRPM8 is one of the key events causing the ambienttemperature-dependent changes in temperature thresholds for TRPM8 activation, precisely how $\mathrm{PIP}_{2}$ behaves in a temperature-dependent manner in response to high exposed temperature is not completely clear. There are several possible mechanisms that could explain the phenomenon. One is a change in the amount of cellular $\mathrm{PIP}_{2}$ depending on the ambient temperature fluctuation. Indeed, Yudin et al. (2011) found a reduction in cellular PIP $_{2}$ upon temperature decrease (from $25^{\circ} \mathrm{C}$ to $10^{\circ} \mathrm{C}$ ) using fluorescence-based PIP $_{2}$ level measurements. Although we tried to investigate the changes in PIP $_{2}$ levels using a similar FRET system, both CFP and YFP signals decayed in a temperature-dependent manner at high exposed temperatures $\left(>30^{\circ} \mathrm{C}\right)$, making it difficult to measure $\mathrm{PIP}_{2}$ levels. Alternatively, $\mathrm{PIP}_{2}$ recruitment near TRPM8 proteins in the plasma membrane or changes in the extent of $\mathrm{PIP}_{2}$ interaction with TRPM8 could occur depending on the changes in ambient temperature. Further analysis is required to clarify the precise mechanisms underlying the ambienttemperature-induced events. Nonetheless, it is clear that temperature thresholds for TRPM8 activation can be changed dynamically within a few minutes and that such changes occurred when environmental temperatures increased or decreased (Fig. 1C,E). These results indicate that reversible events are probably involved.

Daniels et al. (2009) reported that rat TRPM8-mediated $\mathrm{Ca}^{2+}$ influx activated PLC, thereby decreasing PIP $_{2}$ levels and resulting in reduced rTRPM8 activity, although they did not observe the changes in temperature thresholds for activation. There are several differences between our experimental conditions and theirs. The main differences between the two studies are the methods used for measuring TRPM8 activity and the applied temperature ranges. Daniels et al. measured temperature thresholds for rTRPM8 activation using a $\mathrm{Ca}^{2+}$-imaging method with temperatures up to $33^{\circ} \mathrm{C}$, whereas we used a patch-clamp method in a temperature range between $30^{\circ} \mathrm{C}$ and $40^{\circ} \mathrm{C}$. We did not observe clear changes in temperature thresholds for hTRPM8 activation at $30^{\circ} \mathrm{C}$, consistent with the data by Daniels et al. However, we observed significant differences in the thresholds at temperatures $>35^{\circ} \mathrm{C}$. Temperature ranges at which experiments were performed seem to be a critical determinant causing different outcomes. In addition, we observed the exposed-temperaturedependent changes in temperature thresholds for hTRPM8 activation regardless of the presence or absence of extracellular $\mathrm{Ca}^{2+}$, making the involvement of $\mathrm{Ca}^{2+}$ influx in the phenomenon less likely. The finding that $\mathrm{Ca}^{2+}$ influx through hTRPM8 activation upon repetitive cold stimuli increases and decreases the temperature thresholds for TRPM8 activation depending on the direction of solution temperature change supports the idea.

In the present study, we used several methods to change the level of cellular PIP $\mathrm{P}_{2}$. One might imagine that such changes would alter temperature thresholds for TRPM8 activation at both $30^{\circ} \mathrm{C}$ and $40^{\circ} \mathrm{C}$. However, significant temperature threshold changes were observed only when the environmental temperature was $40^{\circ} \mathrm{C}$. In addition, exogenous application of $\mathrm{diC}_{8} \mathrm{PIP}_{2}$ did not cause any change in temperature threshold (Fig. 2). We currently cannot explain these findings. Temperature thresholds in the absence of additional TRPM8 agonists under naive conditions might be tightly regulated to a constant temperature of $\sim 28^{\circ} \mathrm{C}$. Alternatively, it might be hard to detect small changes with our system. In any case, the fact that heat-sensing ability is affected by changes in ambient temperature (Tritsch, 1990) suggests that there might be a universal or common mechanism leading to the changes in temperature-sensing ability. More studies are required to better understand the temperature-sensing mechanisms underlying these processes.

\section{References}

Andersson DA, Chase HW, Bevan S (2004) TRPM8 activation by menthol, icilin, and cold is differentially modulated by intracellular $\mathrm{pH}$. J Neurosci 24:5364-5369. CrossRef Medline

Bandell M, Dubin AE, Petrus MJ, Orth A, Mathur J, Hwang SW, Patapoutian A (2006) High-throughput random mutagenesis screen reveals TRPM8 residues specifically required for activation by menthol. Nat Neurosci 9:493-500. CrossRef Medline

Benedikt J, Teisinger J, Vyklicky L, Vlachova V (2007) Ethanol inhibits coldmenthol receptor TRPM8 by modulating its interaction with membrane phosphatidylinositol 4,5-bisphosphate. J Neurochem 100:211-224. CrossRef Medline

Brauchi S, Orio P, Latorre R (2004) Clues to understanding cold sensation: thermodynamics and electrophysiological analysis of the cold receptor TRPM8. Proc Natl Acad Sci U S A 101:15494-15499. CrossRef Medline 
Caterina MJ, Schumacher MA, Tominaga M, Rosen TA, Levine JD, Julius D (1997) The capsaicin receptor: a heat-activated ion channel in the pain pathway. Nature 389:816-824. CrossRef Medline

Chuang HH, Prescott ED, Kong H, Shields S, Jordt SE, Basbaum AI, Chao MV, Julius D (2001) Bradykinin and nerve growth factor release the capsaicin receptor from PtdIns(4,5)P2-mediated inhibition. Nature 411: 957-962. CrossRef Medline

Chuang HH, Neuhausser WM, Julius D (2004) The super-cooling agent icilin reveals a mechanism of coincidence detection by a temperaturesensitive TRP channel. Neuron 43:859-869. CrossRef Medline

Daniels RL, Takashima Y, McKemy DD (2009) Activity of the neuronal cold sensor TRPM8 is regulated by phospholipase $\mathrm{C}$ via the phospholipid phosphoinositol 4,5-bisphosphate. J Biol Chem 284:1570-1582. CrossRef Medline

Estacion M, Sinkins WG, Schilling WP (2001) Regulation of Drosophila transient receptor potential-like (TrpL) channels by phospholipase C-dependent mechanisms. J Physiol 530:1-19. CrossRef Medline

Hilgemann DW, Feng S, Nasuhoglu C (2001) The complex and intriguing lives of PIP2 with ion channels and transporters. Sci STKE 2001:re19. CrossRef Medline

Horowitz LF, Hirdes W, Suh BC, Hilgemann DW, Mackie K, Hille B (2005) Phospholipase $\mathrm{C}$ in living cells: activation, inhibition, $\mathrm{Ca}^{2+}$ requirement, and regulation of M current. J Gen Physiol 126:243-262. CrossRef Medline

Iwasaki H, Murata Y, Kim Y, Hossain MI, Worby CA, Dixon JE, McCormack T, Sasaki T, Okamura Y (2008) A voltage-sensing phosphatase, Ci-VSP, which shares sequence identity with PTEN, dephosphorylates phosphatidylinositol 4,5-bisphosphate. Proc Natl Acad Sci U S A 105:7970-7975. CrossRef Medline

Kashio M, Sokabe T, Shintaku K, Uematsu T, Fukuta N, Kobayashi N, Mori Y, Tominaga M (2012) Redox signal-mediated sensitization of transient receptor potential melastatin 2 (TRPM2) to temperature affects macrophage functions. Proc Natl Acad Sci U S A 109:6745-6750. CrossRef Medline

Knowlton WM, Bifolck-Fisher A, Bautista DM, McKemy DD (2010) TRPM8, but not TRPA1, is required for neural and behavioral responses to acute noxious cold temperatures and cold-mimetics in vivo. Pain 150: 340-350. CrossRef Medline

Liu B, Qin F (2005) Functional control of cold- and menthol-sensitive TRPM8 ion channels by phosphatidylinositol 4,5-bisphosphate. J Neurosci 25:1674-1681. CrossRef Medline

Liu D, Liman ER (2003) Intracellular $\mathrm{Ca}^{2+}$ and the phospholipid PIP2 regulate the taste transduction ion channel TRPM5. Proc Natl Acad Sci U S A 100:15160-15165. CrossRef Medline

Mälkiä A, Madrid R, Meseguer V, de la Peña E, Valero M, Belmonte C, Viana F (2007) Bidirectional shifts of TRPM8 channel gating by temperature and chemical agents modulate the cold sensitivity of mammalian thermoreceptors. J Physiol 581:155-174. CrossRef Medline

McKemy DD, Neuhausser WM, Julius D (2002) Identification of a cold receptor reveals a general role for TRP channels in thermosensation. Nature 416:52-58. CrossRef Medline

Morenilla-Palao C, Pertusa M, Meseguer V, Cabedo H, Viana F (2009) Lipid raft segregation modulates TRPM8 channel activity. J Biol Chem 284:9215-9224. CrossRef Medline

Moriyama T, Higashi T, Togashi K, Iida T, Segi E, Sugimoto Y, Tominaga T, Narumiya S, Tominaga M (2005) Sensitization of TRPV1 by EP1 and IP reveals peripheral nociceptive mechanism of prostaglandins. Molecular Pain 1:3-12. CrossRef Medline

Nakanishi S, Catt KJ, Balla T (1995) A wortmannin-sensitive phosphatidylinositol 4-kinase that regulates hormone-sensitive pools of inositolphospholipids. Proc Natl Acad Sci U S A 92:5317-5321. CrossRef Medline

Park U, Vastani N, Guan Y, Raja SN, Koltzenburg M, Caterina MJ (2011) TRP vanilloid 2 knock-out mice are susceptible to perinatal lethality but display normal thermal and mechanical nociception. J Neurosci 31: 11425-11436. CrossRef Medline

Peier AM, Moqrich A, Hergarden AC, Reeve AJ, Andersson DA, Story GM, Earley TJ, Dragoni I, McIntyre P, Bevan S, Patapoutian A (2002) A TRP channel that senses cold stimuli and menthol. Cell 108:705-715. CrossRef Medline

Rohács T, Nilius B (2007) Regulation of transient receptor potential (TRP) channels by phosphoinositides. Pflugers Arch 455:157-168. CrossRef Medline

Rohács T, Lopes CM, Michailidis I, Logothetis DE (2005) PI(4,5)P2 regulates the activation and desensitization of TRPM8 channels through the TRP domain. Nat Neurosci 8:626-634. CrossRef Medline

Runnels LW, Yue L, Clapham DE (2002) The TRPM7 channel is inactivated by PIP(2) hydrolysis. Nat Cell Biol 4:329-336. CrossRef Medline

Tominaga M, Caterina MJ (2004) Thermosensation and pain. J Neurobiol 61:3-12. CrossRef Medline

Tritsch MF (1990) Temperature sensation: the "3-bowls experiment" revisited. Naturwissenschaften 77:288-289. CrossRef Medline

Voets T, Droogmans G, Wissenbach U, Janssens A, Flockerzi V, Nilius B (2004) The principle of temperature-dependent gating in cold- and heatsensitive TRP channels. Nature 430:748-754. CrossRef Medline

Yudin Y, Lukacs V, Cao C, Rohács T (2011) Decrease in phosphatidylinositol 4,5-bisphosphate levels mediates desensitization of the cold sensor TRPM8 channels. J Physiol 589:6007-6027. CrossRef Medline

Zakharian E, Cao C, Rohács T (2010) Gating of transient receptor potential melastatin 8 (TRPM8) channels activated by cold and chemical agonists in planar lipid bilayers. J Neurosci 30:12526-12534. CrossRef Medline

Zhang X, Mak S, Li L, Parra A, Denlinger B, Belmonte C, McNaughton PA (2012) Direct inhibition of the cold-activated TRPM8 ion channel by Galphaq. Nat Cell Biol 14:851-858. CrossRef Medline 